ELORE (ISSN 1456-3010), vol. 16 - 2/2009.

Julkaisija: Suomen Kansantietouden Tutkijain Seura ry.

[http://www.elore.fi/arkisto/2_09/haastattelu_salminen1_2_09.pdf]

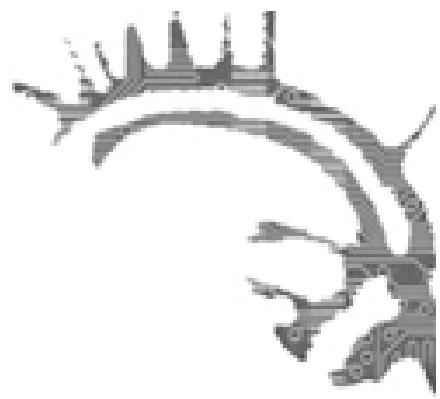

\title{
ETNOLOGI, VASTARANNANKIISKI JA EMERITUSPROFESSORI HaAstattelussa Bo Lönnqvist
}

\author{
$\underline{\text { Elina Salminen }}$
}

Professori Bo Lönnqvist aloitti uransa Jyväskylän yliopiston etnologian professorina vuoden 1995 alussa ja jäi eläkkeelle loppuvuodesta 2004. Kymmeneen virkavuoteen mahtui paljon kaikenlaista. Lönnqvist uudisti opetussuunnitelmia ja jyväskyläläisen etnologian lähtökohtia, otti kantaa yliopiston sisäisiin, hallinnollisiin uudistuksiin, teki tiedettä ja vaikutti ympäristöönsä. Jyväskylän yliopiston Seminaarinmäen liepeillä sijaitsevan lähikaupan kassatkin tunsivat hänet; hänellä kun oli tapana pysähtyä puhumaan ihmisten kanssa ja tehdä kenttätöitä tilanteessa kuin tilanteessa. Kenttätyön merkityksen korostaminen teki lähtemättömän vaikutuksen etnologian opiskelijoihin ja jatkuu etnologian korostettuna profilina Jyväskylässä edelleen.

Tapasin Bo Lönnqvistin Helsingissä Akateemisen kirjakaupan kahvilassa lokakuussa 2009. Keskustelimme leivoskahvien ääressä elämästä ja etnologiasta. Tapaaminen nosti mieleeni muistoja siitä kuinka istuimme päivittäin kello yhdeksän aamulla ja kello kaksi iltapäivällä Jyväskylän yliopiston Villa Rana -rakennuksen kansliassa pöydän ääressä puhuen ihmisistä, tieteestä ja maailmanmenosta. Mukana oli etnologian henkilökuntaa, jatko-opiskelijoita ja joskus opiskelijoitakin.

\section{INNOSTUS KANSATIETEESEEN}

Filosofian ylioppilas Lönnqvist aloitti opintonsa Helsingin yliopistossa 1950-luvun lopussa pääaineenaan pohjoismainen filologia. Hänen tähtäimessään oli äidinkielen opettajan pätevyys. Jo ennen opintojen aloittamista, koulupoikana, hän oli kuitenkin osoittanut kiinnostusta kansatieteeseen osallistumalla Kansallismuseon ja Seurasaarisäätiön keruukilpailuihin. Ajatukset kulttuuriperinnön säilyttämisestä, yhteisöllisestä muistista sekä katoavan pelastamisesta alkoivat siis kehittyä käytännön keruutyön kautta. Samalla hän tutustui alalla vaikuttaviin ihmisiin, muun muassa dosentti Toini-Inkeri Kaukoseen, joka Kansallismuseon puolesta organisoi keruukilpailuja. Kansatieteen sivuaineopintojen pariin Lönnqvist päätyi historian kautta jatkaen aina laudaturiin (nykyisin syventävät opinnot) asti. 


\section{Elina Salminen}

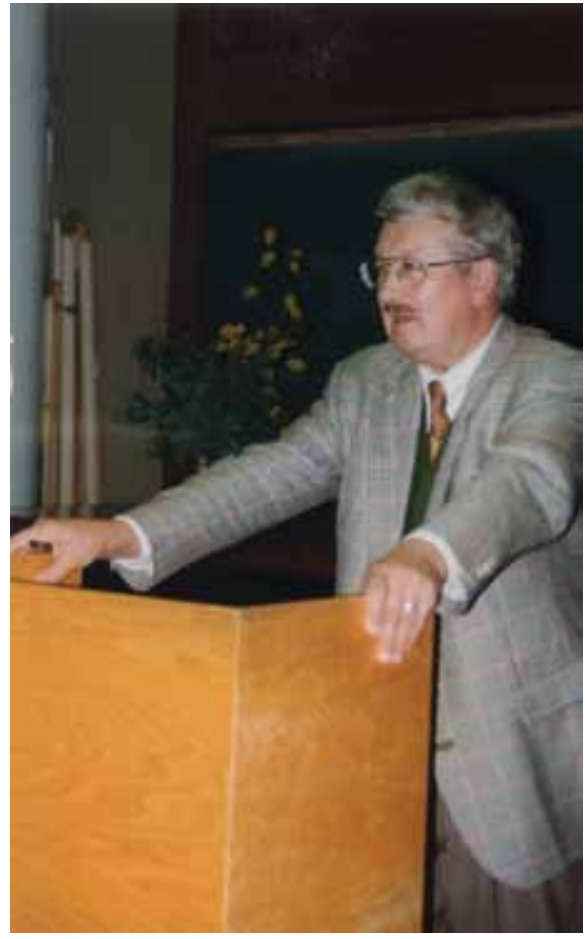

Bo Lönnqvist esitelmöimässä Villa Ranan Paulaharju-Salissa joskus 1990-luvulla Elina Salmisen kuvaamana.
Lönnqvist joutui puoliksi sattumalta yliopiston assistentiksi pohjoismaiseen filologiaan ja sitten, kasvatustieteen professori Gunnar Stadiuksen houkuttelemana, tutkijan uralle. Hänen ensimmäinen vakituinen tutkijan paikkansa oli SLS:n (Svenska Litteratursällskapet i Finland) arkistossa (Folkkultursarkivet), jossa hän oli työskennellyt opiskeluaikoinaankin. Ajalle tyypillinen etnologinen ote oli hänelle opintojen aineyhdistelmän vuoksi otollinen:

minulla oli ne kansatiede ja kielitiede, kun se oli sitä Wörter und Sachen -tutkimusta silloin. Ja siitä minun etnologinen elämäni alkoi kasvaa, kun työskentelin arkistonhoitajana tässä, kuten sanottiin, kansatieteellisessä arkistossa. Ja siellä minä työskentelin vuoteen 1973, jolloin Valonen oli juuri saanut läpi yleisen etnologian tuolin, ja minä boidin sitä kunnes siihben löydettiin joku - - työ oli aika vapaata, ja olin mahdollisundessa alkaa tehdä kenttätöitäjoka kesä, kaikki ne baastattelut ja munta. Opin paljon siellä työskennellessäni.

Tutkijuus vei Lönnqvistin mennessään. Hän aloitti jatko-opinnot kansatieteessä ja väitteli vuonna 1972 pukeutumisen kansanomaisista ja muotipiirteistä maalaisyhteisössä 1800- ja 1900-lukujen vaihteessa. Väitöskirjasta voi löytää strukturalistisia piirteitä.

\section{TutKIJANA}

Työskennellessään SLS:n arkistossa Lönnqvist oli kerännyt mittavan aineiston, jota hän alkoi analysoida toimiessaan tutkijana. Hänen tutkijanuransa läpäiseviä piirteitä on se, että hänellä on ollut taipumus palata vanhoihin aineistoihin ja analysoida niitä uusin ajatuksin. Toisaalta hän on surutta vaihtanut tutkimusaihetta, kun on saanut tutkimuksensa valmiiksi - hänen tieteellinen tuontantonsa onkin varsin laaja-alainen.

1970-1980-luvuilla Suomen Akatemia myönsi tutkijarahoitusta pitkäaikaisesti. Akatemian rahoituksella Bo Lönnqvistin oli mahdollista toimia tutkijana useita vuosia peräkkäin, vaikka hän suhtautuukin itse mittavaan kauteensa hieman haikean huvittuneesti:

Kaikkiaan työskentelin Suomen Akatemian rahoituksella seitsemäntoista vuoden 


\title{
EtNOLOGI, VASTARANNAN KIISKI JA EMERITUSPROFESSORI
}

\begin{abstract}
ajan, kausi toisensa jälkeen, ja luulenpa että se on ennätys. Ja, nïn, väbitellen ne sanoivat Akatemiassa, ettei periaatteen vnoksi, en voinut saada untta kautta siellä, he antoivat sitten ybden vuoden lisää armosta, se täytyi olla 1979, tarkoitan 1989-90. Olin jo silloin ajatellut etten voi jä̈dä itselliseksi tutkijaksi enää, ei vaikka olisi ollut taloudellinen mahdollisuus siỉhen, että se rïttää ja minä lähden nyt.
\end{abstract}

Bo Lönnqvistin 60-vuotisjuhlakirjaa varten toimitetussa bibliografiassa on mainittu vuosien 1973-1990 välisenä aikana julkaistuiksi kymmeniä ellei satoja artikkeleita, kommentaareja, kirja-arvosteluja, toimitettuja teoksia sekä monografioita. Tutkimukselliset teemat liikkuivat muun muassa pukeutumisen, kalastuksen, metodien, kansankulttuurin, yhdistystoiminnan, museoiden, kartanoiden, kansatieteen, suomenruotsalaisuuden ja ruotsinkielisyyden, lapsuuden ja kansallispukujen aloilla. Lönnqvist jatkoi samojen teemojen parissa työskentelyä myöhemminkin, syventäen ja laventaen aikaisempia näkökulmia.

\section{OpetTajana}

Suomen Akatemian tutkijatohtoriuden jälkeen Bo Lönnqvist alkoi kartuttaa kokemustaan opettajana, johon tehtävään hän oli saanut muodollisen koulutuksen jo maisterintutkinnossaan. Kokemusta kertyi niin lukiosta kuin yliopistostakin: lyhyttä äidinkielen opettajan kautta lukiossa seurasi vierailevan professorin tehtävä Norjassa. Sieltä hänet kutsuttiin Jyväskylän yliopiston etnologian professorin virkaan, josta edeltäjänsä professori Asko Vilkuna oli jäänyt eläkkeelle jo muutamia vuosia aiemmin. Virkaa oli hoidettu sijaisvoimin. Tuottavuus ja tehokkuus alkoivat samoihin aikoihin esiintyä yliopistojen sisäisissä ja julkisissa keskusteluissa - uudelta professoriltakin edellytettiin tehokkaita toimia pienen oppiaineen tuottavuuden kehittämiseksi ja hyödyllisyyden osoittamiseksi, jollei jopa oppiaineen jatkuvuuden turvaamiseksi.

Lönnqvist pani kaiken uusiksi. Hän harjoitti pedagogista, lähinnä konstruktivistista otetta professorin virassaan aivan alusta saakka ja uudisti niin opetussuunnitelman sisällön kuin opetuksen muodotkin. Opiskelijat saivat nauttia korkeatasoisesta ja lennokkaasta luennoinnista, jonka seuraaminen vaati kuulijoilta keskittymistä. Luentosarjat toteutettiin aiemmasta poiketen lyhyinä ja tiiviinä periodeina. Professori haastoi opiskelijat kysymään, osallistumaan ja soveltamaan kuulemaansa käytännön tilanteisiin. Luentosarjojen tulokset saattoivat näkyä yliopiston ulkopuolella esimerkiksi näyttelyinä Keski-Suomen museossa tai opiskelijoiden kirjoittamina ja toimittamina julkaisuina. Opiskelijat pantiin luennoimaan paikallisiin lukioihin ja Suomen käsityön museon yleisöluentosarjaan.

Lönnqvistille itselleen opetus oli parhaimmillaan vastavuoroista toimintaa, jossa sekä opettaja että opiskelijat oppivat. Tärkeintä opettamisessa on hänen mielestään olla sinut itsensä kanssa: "Nyrkkisääntö kaikessa opettamisessa on, että on oma ittensä, että on aito."

"Olla oma itsensä" vaatii loppumatonta kiinnostusta omaan alaan samoin kuin sen edistämistä kaikin mahdollisin keinoin, kaikilla mahdollisilla kentillä. Lönnqvistille 


\section{Elina Salminen}

professorius merkitsi kaiken sen jakamista, mitä hän oli tieteestä saanut ja ymmärtänyt. Hänen tapansa tehdä etnologiaa tarttui opiskelijoihin: varmasti jokainen hänen aikanaan valmistunut maisteri tunnistaa "lönnqvistläisyyden" itsessään jollain tapaa. Lönnqvistläistä tieteentekemisen ja olemassaolon tapaa hän piti yllä lukemalla jatkuvasti ja selittämällä kahvipöytäkeskusteluissa Villa Ranan kansliassa lukemaansa. Samalla tavalla hän kertoi tapaamistaan ihmisistä ja kokemuksistaan etnologina. Luettu ja kentällä koettu siirtyi sitten teksteihin, joita hän julkaisi. Opettaessaan hän koki aina vaikuttavansa opiskelijoihin tavalla tai toisella.

\section{VAIKUTTAJANA}

Bo Lönnqvistille "omana itsenään oleminen" oli ja on yhä ennen kaikkea uteliaisuutta ja sosiaalista vuorovaikutusta. Hän eksyi kerran jos toisenkin ulkomaisten vieraidensa kanssa illallisen jälkeen kenttätöihin Jyväskylän keskustaan, jossa opiskelijat viettivät fuksiaisia tai suorittivat Kauppakadun approbaturia. Samalla tavalla hän jäi suustaan kiinni kauppojen kassalla, torin kalavaunulla tai vaikkapa Tuurin kyläkaupoissa, jonne hän vei henkilökunnan syksyisin virkistyspäivän merkeissä. Liikkuessaan missä tahansa hän pysähtyi juttelemaan, haastatteli tapaamiaan ihmisiä ja teki vaikutuksen. Etnologian tunnettuus lisääntyi.

Lönnqvistille yliopiston ja Jyväskylän kaupungin osoittama tuki oli tärkeä työssä jaksamisen kannalta. Hän teki tiiviisti yhteistyötä kaupungin kanssa 1990-luvulla perustetussa Jyväskylä-Foorumissa, jonka idea oli saada kaupunkilaiset, virkahenkilöt ja asiantuntijat keskustelemaan kaupungin tulevaisuudesta ja siihen liittyvistä erilaisista teemoista. Jyväskylän kaupunki rahoitti etnologian tutkimushankkeita, jotka liittyivät kaupungin suunnitteluun ja kehittämiseen.

Lönnqvist piti esitelmiä erilaisten järjestöjen ja yhdistysten kokouksissa, antoi - vaikkakin harkiten - haastatteluja tiedotusvälineille ja ennen kaikkea kohtasi suuren määrän ihmisiä. Hän työskenteli persoonallaan. Samalla tavalla hän toimi tieteen kentässä: verkostoitui ja jakoi verkostonsa. Esimerkiksi heti tultuaan professoriksi Lönnqvist kehitti yhdessä silloisen amanuenssin Eeva Uusitalon kanssa opiskelijoiden vaihtoopiskelumahdollisuuksia omien kontaktiensa pohjalta ja esitteli jatko-opiskelijansa etnologituttavilleen, joiden aiheen katsoi hyödyttävän tohtorikoulutettavien työtä. Yhä edelleen työterveyslääkärit ja lähikaupan kassat muistavat hattupäisen, viitassaan kävelevän Lönnqvistin ja kyselevät hänen kuulumisiaan.

\section{EMERITUKSENA}

Mitä Bo Lönnqvist ajattelee työstään etnologian professorina nyt, kun on viettänyt melkein viisi vuotta eläkeläisenä? Mitä hän sai aikaan, ja mihin suuntaan etnologia on menossa? Mitä hänelle itselleen on tapahtunut viiden vuoden aikana?

Lönnqvist kommentoi tapaansa työskennellä seuraavasti: 


\section{Mun luonteelle sopi se, että pani itsensä likoon. Ja kyllä professorilla on velvollisuus kebittää itseään.}

Panemalla itsensä likoon Lönnqvist vaikutti siihen, että etnologian oppiaine Jyväskylän yliopistossa säilyi itsenäisenä, vaikkakin pienenä oppiaineena ja tieteenalana. Itsenäisenä ja omaperäisenä säilyi myös sen tieteellinen luonne, jota Lönnqvist kehitti omaan suuntaansa. Merkittävänä saavutuksenaan Lönnqvist pitää vaikuttamista ihmisiin niin ruohonjuuri- kuin pätöksentekotasollakin. Erityisen tärkeitä hänelle ovat opiskelijat, joiden kanssa hän edelleen mieluusti on yhteyksissä. Vaikeaksi työssään professorina hän koki johtamisen ilman minkäänlaista koulutusta:

\section{Eibän mulla ollut mitään esimieskoulutusta. Piti oppia tuntemaan kaikkkia sïnä työybteisössä ja mistä voi tulla konflikteja.}

Nykyisin koulutusta on olemassa, mitä Lönnqvist pitää hyvänä asiana. Samoin on olemassa ohjeistusta ulkopuolisen rahoituksen hankkimiseen ja verkostoitumiseen, jotka Lönnqvistille olivat enemmänkin luontainen tapa toimia kuin tieteen tekemiseen ulkoapäin asetettu vaade.

Emeritusprofessori työskentelee edelleen. Hänen professori Gábor Barnan kanssa aloittamansa tutkimusprojekti Banatin alueen unkarilaisten keskuudessa jatkuu, onpa Lönnqvist alkanut opiskella unkarin kieltäkin kun siihen nyt on aikaa. Samoin jatkuu hänen professori Toivo Nygårdin 60-vuotisjuhlakirjaa varten kirjoittamansa Albert Edelfeltin taulua Kaarle Herttua herjaa Klaus Flemingin ruumista (1878) käsittelevän artikkelin innoittamana virinnyt projekti. Siinä Lönnqvist tarkastelee maalaustaidetta monitieteisesti erilaisten tulkintojen lähteenä. Lönnqvist luennoi Tukholman yliopiston modevetenskap-maisteriohjelmassa, kuten myös Unkarissa, Szegedissä kollegansa, professori Barnan kotilaitoksessa. Hän opettaa, kirjoittaa, tekee kenttätöitä ja lukee. Emerituksena hänellä on kuitenkin mahdollisuus tehdä asiat omaan tahtiinsa. Tahti ei liene kovin hidas, koskapa kustantajansa on kommentoinut sitä sanomalla, että ostajat menevät sekaisin kun Lönnqvistin kirjoja on markkinoilla useita samana vuonna!

Mitä Bo Lönnqvist antaisi saatteeksi uudelle etnologian professorille Hanna Snellmanille? Hän toivoo, että Snellman jatkaa lönnqvistläistä "kansanvalistuksen" linjaa ja on läsnä yliopistossa, kaupungissa ja maakunnassa. Erityisesti Jyväskylässä on hänen mukaansa helppo verkostoitua. Samoin hän toivoo, että uusi professori tekee oppiainettaan tunnetuksi julkaisemalla - vaikkei se tieteellisesti meritoivaa olekaan populaaritieteellisiäkin teoksia, jotka innostavat tiedemaailman ulkopuolisia ihmisiä tutustumaan etnologian tapaan tarkastella ympäröivää maailmaa tai omaa arkeamme. Hän toivoo, että Snellman panisi persoonansa likoon muistaen, että "ei tää oo perkele kyllä ihan normaalityötä”.

Filosofian maisteri Elina Salminen työskentelee amanuenssina Jyväskylän yliopistossa ja viimeistelee väitöskirjaansa julkisen ja yksityisen välisistä rajapinnoista omistamisen, keräilyn ja museoimisen kentillä. 